\title{
A quest to quantify urban sustainability. Assessing incongruous growth
}

\author{
Malgorzata Hanzl' ${ }^{1}$, Lia Maria Dias Bezerra ${ }^{2}$, Anna Aneta Tomczak ${ }^{1}$, \\ Robert Warsza ${ }^{1}$ \\ ${ }^{1}$ Institute of Architecture and Town Planning. Lodz University of Technology. Poland; ${ }^{2}$ Faculty of \\ Architecture, Warsaw University of Technology, Koszykowa. Poland \\ E-mail:mhanzl@p.lodz.pl, lia.bezerra@pw.edu.pl, \\ aneta.tomczak@p.lodz.pl,rwarsza@op.pl
}

\begin{abstract}
Urban planners, politicians and citizens need comprehensive and clear information in order to conduct or to get involved in successful evidence-based planning and policymaking. The objective to improve the quality of planning outcomes both at the local and regional level needs design mechanisms that can help verify and support urban planning approaches with quantitative analyses and simulation tools. While this issue has been explored through extensive literature on the topic, there is still plenty to research further, especially when dealing with the evaluation of plans, such as local plans of urban development, comprehensive plans, municipal studies or larger planning involving multiple municipal associations. The use of quantitative analyses may be applied to several aspects of the physical form, including connectivity, ecological system continuations, built structure conciseness and its urban boundary, urban tissue morphology, among others. Quantitative analyses completed by qualitative description and enriched with socio-cultural assessment can result in a comprehensive picture of an area's current and planned state. This paper presents our experience with mapping residential structure typologies in Lodz, Poland and its surroundings. This mapping assessed the existing residential densities and planned development capacities considering the area's demographic dynamics in the background. The method revision is completed by examples of open green space quality assessment.
\end{abstract}

Keywords: Urban Morphology, Population Density, Quality of Life, GIS.

\section{Introduction}

The configuration of urban areas plays a key role in its sustainability. Sustainable planning outcomes at local and regional level need support from urban planners and designers, segments of the civil society, stakeholders and authorities. Efficient and coherent planning needs comprehensive and verifiable outcomes on which to base their approaches and policymaking (Faludi and Waterhout 2006). Verifiable outcomes are able to become inputs for direct evaluations of urban policies.
Quantitative and qualitative analyses and simulation tools should pragmatically sustain decisions. Particularly, quantitative methods need to be applied to many aspects of the urban structures.

Density analyses are one of the aspects that need a careful look upon. Density primarily supports the relation between population dynamics and physical development, which constitutes a key factor of sustainable urban development. Residential capacity derives from population density and also plays an important role in analyses supporting planning 
decisions. The adequate configuration of urban areas is essential to provide responsible urban settlements in the age of scarcity and rapid land consumption for all of its inhabitants. The assessment of quality of life in and sustainability of urban areas demands researches and definitions that touch both qualitative and quantitative criteria.

Suitable data analyses are run using suitable databases that aren't always available. Data that provide the basis for urban analyses have been progressively available, especially with the help of GIScience. The INSPIRE Directive in Europe, official land information releases, as well as data from crowdsourcing, free satellite imagery and other open source data creates opportunities to establish a set of available methods and tools that can support decisions on future developments (Hanzl and Bezerra in press). The developing agreement on urban indicator standards also helps in building a verifiable and comparable outcome.

We review applied methods of estimating density and residential capacity. On this backdrop, we present an application of urban morphology analysis illustrated by case studies in Lodz and other neighbouring settlements in Poland. We also address the assessment of quality of life through the existence of publicly accessible green areas and public spaces in urban settings.

\section{Urban Density versus Open Space Provision}

Cities that strive to achieve sustainability do so by taking into consideration the rationale for compact city development, by taking care of the natural and social resources and by understanding their population dynamics. The quest to relate the ecological perspective to population growth and therefore land consumption is almost controversial. While urban population grows, city boundaries expand at an unprecedented speed (Angel et al 2011), absorbing their greener outskirts and diminishing its gross urban population density. Although contemporary urban trends emphasise higher population densities, it has been diminishing de facto. There is far too much city space given to transportation infrastructure that adds to underutilised city voids or open areas. Newman and Kenworthy (1999) suggest an urban commons view that makes open public areas, parking and roadway spaces the focus of urban renewal and redesign. They bring together the notion of a very urban city, compact within itself, with environmental quality, urban greening, commitment to the city and its public values.

Urban population density is one of the tools that can propose concise urban development while preserving open space areas that might be dedicated to other activities that collaborate to urban sustainable development. Concentrated urban development can present higher urban density and simultaneously help to preserve agricultural, forests or other types of green areas on cities' outskirts. A planned urban densification can improve quality of life. However, planning needs to make formal provisions that connect number of inhabitants, therefore, a certain density, also to an amount of open and green areas.

The current situation in Poland mimics the uncontrolled market-induced, suburbanized land consumption that has happened in North America and Western Europe half a century ago. The socialist tradition of building isolated midrise residential blocks in the cities' outskirts has been incentivized by the lack of strategies for a compact city development or planning, expensive urban land, unknown ownership, and overly long and complicated development approval procedures within cities. City development has been dissociated to population dynamics, including density requirements. The recent 'Amending Act for the Strengthening of Landscape Protection' (PP2015) has started to associate population dynamics and the amount of urban land required for new developments, but it still doesn't have proper legislation.

The provision of open spaces brings both advantages and disadvantages to urban sustainability. While open spaces, and especially parking areas, new streets and areas dedicated to vehicular transport, has to be introduced with due care and limited in scale, the advantages of open spaces can be considered mainly twofold. Open spaces contribute to both social and environmental aspects of the urban area. First, it provides leisure 
opportunities and spaces for encounters, as plazas, parks and community gardens. Second, it can be a space where an area's ecological needs are attended by establishing a protected area, improving its natural habitat or even by alleviating the pressure on urban infrastructure through the application of green technologies. Either advantages are not excluding, but rather complementary.

\section{Density Measurements}

Density is the ratio between a given quantity and a unit of area. When applied to urban planning and design it can be used for a number of analyses, as an amount of population, dwellings or built spaces per unit of area. Density is a concept that has a broad application and a simple definition, but there is no established consensus applied to urban planning (Alexander 1993, Churchman 1999), which can hinder the comparison between areas, cities, and countries. Density comparisons can be difficult to realise, therefore its methodology needs to be clearly defined from the beginning. Within the definition of density, net and gross values can vary, as well as scales and area averages, which can change the interpretation of the results - if compared. This is mostly due to one of the most problematic and important definition for density outcome, according to BerghauserPont and Haupt (2010): the definition of the boundary area. However the outcome, a density measurement is a neutral indicator, and it does not express a judgment or automatically relate to any given morphological typology. Density measurements applied to urban planning can refer to an amount of dwellings, built spaces or population in a given area.

\section{Residential Density Estimation Methods}

Population density measurement relates the amount of a city's area to its population dynamics. It is one of the most basic and widely used types of density measurements applied to urban planning, as it is found in various planning documents and plans stating the preliminary assumptions for an area with residential use. Even though it can be found in many documents, it is not always a mandatory requirement. Poland's planning legislation does not bind population density to its plans, for example. Only recently the use of demographic forecasts as the background for the elaborations of Study of Conditions and Directions of Spatial Development has become mandatory (PP 2015); however, the implementation regulations have yet to be defined. The lack of this basic relation among number of inhabitants and land area can generate waste of resources and infrastructure - especially undesired consumption of green land.

Estimations on urban population distribution have been experimented with since midtwentieth century. The range of application criteria includes workload and reliability, as well as the requirements of a given task and data available. The traditional method to analyse sample areas usually remains expensive and is time demanding. A gravitational mathematical model was created by Clark (1951) to show how population distribution is affected by its city's formation and population dynamics. Clark's model relates population distribution with distance to the centre, in analogy to the differentiation of urban fabric along this same axis. Other statistical models were developed throughout the following decades along with the use of laser, remote sensing and crowdsourcing towards the turn of the XXI century. The application of GIScience has also contributed to efficient estimation. However, these types of data are not always available for analysis. Therefore other, more traditional methods to approach residential densities are still used.

The use of building footprint for urban planning and design is one of the most common approaches. By surveying building footprints and moreover plot and parcel data, a database is built on which dwelling size, building footprint, Floor Area Ratio (FAR) plays a part in estimating residential population density and moreover its capacity. The method may either consist of summarising numbers of inhabitants per dwelling or use predefined dwelling densities, then assigning a density to 
building footprints or FAR parameters, which results in capacities values. The survey can be done by hand, or facilitated by the use of cadastral data, but can become cumbersome. GIS technologies play its part in optimising the processes and analyses. Smith and Crooks (2010) elaborated a version of such method for London that used address points to obtain data on number of dwellings per building.

\section{Morphological Typology Approach}

The survey method may use a morphological classification of the built typologies, stemming from their historical transformation and shaped by cultural and civilizational factors. The morphological method makes into account the basic features of the area: (1) parcellation either from comprehensive plans or cadastral data; (2) building forms and typologies; and (3) land use activities, function or land use. The use of these three features also defines a Conzenian urban region (Baker, Slater 2000).

Planners may use the morphological approach at various scales, starting from the city level and down to much more accurate scales of Local Plans of Urban Development. Usage of GIS significantly enhances the method's flexibility, thanks to the easiness to add or alter features' attributes. Moreover, the systematic approach enables urban form's definition consistency throughout one or more documents.

In 2002, a team headed by Mirosław Wiśniewski applied this morphological method for the evaluation of the city of Lodz's urban structure. The results of this analysis featured in the Study of Conditions and Directions of Urban Development (2002). The assessment, which addressed the whole town area within its administrative borders, was made possible thanks to the application of GIS database (Hanzl 2003). The method used morphogenetically uniform units, which varied in size from one to a dozen of land plots.

To distinguish the smallest morphogenetical units, Wiśniewski's team applied attribute concatenation. Features taken into consideration included the type of land-use, the form of built structures and parcellation properties. A given category featured similar types of urban fabric, for instance, downtown tenements or modernism blocks of flats, if their parcel divisions belonged to the same class and were from the same period. Urban open green spaces, such as parks or cemeteries made another category. The level of completeness, determined individually for each type of land use, added to the characteristics and enabled further estimations of future capacities. Combined values from several fields contributed to a matrix that defined the type of each single record.

The development of this morphological methodology has entered the curriculum of the Urban Structure Division in the Institute of Architecture and Town Planning at the Lodz University of Technology, headed by Prof. Weronika Wiśniewska after Prof. Jacek Wesołowski, and by the research conducted within the division, as Warsza (2012).

The initial framework of the morphological types serves as a basis to calculate population densities. Density values assigned to morphological categories enable the estimation of population capacities. The extent of a basic unit, which typically covers more than one single lot, increases the speed of the calculation process in comparison to other methods, described previously. During the seminar 'Sustainable Development in Urbanism' (Urbanistyka w rozwoju zrównoważonym) in 2016, students mapped residential typologies in the towns surrounding Lodz, Poland. One of the students' works is shown in Figure 1. As a next step they assess existing and potential densities and population capacities, both for the current situation and planned development. The results are further analysed taking into consideration the town's demographic dynamics.

Students of the Architecture for the Society of Knowledge master level program in the Faculty of Architecture at the Warsaw University of Technology used a similar method during the course "GIS - Parametric Description of Urban Space", tutored by M. Hanzl (Fig.2). They calculated the density capacity for Góra Kalwaria, Poland, using GIS aided by WMS data available through INSPIRE. This experience proved that morphological typology introduced as a framework for further 
measurement of population densities enhances computation speed and facilitates the analytical process in comparison to other methods. It is especially useful when there is insufficient cadastral data available from the authorities. Compared to the results of the course mentioned above, the application of GIS software for this task significantly improved its efficiency.

\section{Residential Capacity}

A carrying capacity derives from ecology and establishes a cap for the amount of activity that an environment can bear without cause damage to itself, therefore a maximum development density should be the limit for an urban setting (Oh et al 2004). The residential capacity is measured as the maximum amount of residential activity that an area can have without causing environmental, social or economical distress. Its measurement is conceived as a predefined set of parameters and is derived from the existing densities of population and physical structures. The residential capacity has been applied to the calculations of future densities for Lodz's downtown for the Study of Conditions and Directions of Urban Development currently being elaborated for Lodz. The population densities forecasts were obtained based on statistical data and aggregated to transportation units through the estimation of future capacities. These urban structures' future capacities were derived from the regulations of the documents of Local Plan of Urban Development approved for the downtown area, and aggregated to the same units. Figure 3 shows the population densities forecasts for 2015, 2020 and 2025.

The residential capacities were estimated using the Conzenian morphological approach, which enabled the estimation of both of current population densities as well as proved the available potential to further densify central areas. Lodz, which is the capital of the voivodeship and was the second largest city in Poland until 2006, has been rapidly depopulating since the beginning of the 1990s because of a crisis in the textile industry. The decrease of the population in the region's capital has further worsened through the spatial planning policy of its surrounding towns and lack of coherent regional strategy. Migration to smaller towns and villages in the area are the results of better quality of life in small towns with former citizens of Lodz seeking especially the abundance of open green areas in the suburbs. The planning study currently under elaboration contributes to the larger strategy of Lodz municipality to deal with this problem.

\section{Quality of Life Measurement: Open Spaces' Role}

Open spaces in the middle of developed urban land present a challenge to urban planning, as it is placed in valuable urban land fully connected to the urban infrastructure. Open spaces directly compete with the potential of creating more living and working spaces for the urban population. The provision of open spaces directly influences urban density as a nominal factor.

The assessment of urban settlements in relation to its sustainable development features many specific themes, such as is defined in the norm ISO 37120:2014, which is currently under review. This norm defines and establishes a comprehensive set of standardised indicators that evaluate city services and quality of life. These precise definitions enable comparisons between cities despite size and location, without defining an ideal level range. Measurement comparisons become a useful tool for city managers, politicians and planners.

A quantitative measurement of urban voids or open spaces along with other measures of the physical urban environment can demonstrate the varying degree of influence of each component in the overall urban life quality assessment. Directly, these voids (or open spaces) have an implication on population gross densities values. Open spaces can be considered green areas, such as parks, landscaped plazas, smaller squares and also streets or pathways. Streets also fulfil significant social functions, beside their transportation role. The increase in area of these open spaces decreases the gross population density, as it adds area without a residential population. 
Among the methods that measure the role of open spaces in urban quality enhancement, many are focused on the current presence of vegetation - namely trees. Vegetation can be identified by field measurements, satellite and laser data analysis. However the method chosen for identification, it is important to quantify them in urban areas. Urban vegetation and more precisely number of trees is widely recognised due to improvements in the urban climate by reducing the impact of heat islands, diminishing noise and improve the quality of air (Roloff 2016).

In the specific case of Lodz's Study of Conditions and Directions of Urban Development, open spaces were quantified by calculating tree trunks through the use of LIDAR 3D cloud point data. The numbers of trees may be aggregated to urban units of various scales. Fig. 4 shows tree densities in parking areas and streets landscape areas per hectare aggregated by Lodz's municipal information system units (SIM). Fig. 5 illustrates public green areas in square meter per capita. This unit of measurement is especially useful because it facilitates date comparison between various places.

The actual distances from these residential areas to urban green areas, such as parks, cemeteries and urban forests were also assessed. Fig.6a showcases the zones within a 300 meters buffer from public green areas in downtown Lodz. It is accompanied by data on share of people living within a distance of maximum $600 \mathrm{~m}$ from green zones (Fig.6b). Architectural characteristics are also analysed when referring to the quality of open space, as (1) the measured the frequency of heritage structures and other buildings of recognised value; (2) the completeness of urban facades, especially when originally designed as a continuous façade; (3) the presence of defined street corners of streets; (4) the street network density and hierarchy, among others.

\section{Conclusions}

The compactness of urban zone has been recognised as one of the most important conditions of sustainable urban development.
In order to achieve balanced development, the dimensions of urban zone and its capacities to adequately accommodate current and future populations have to be planned responsibly. To establish the correct relations between the sizes of planned urban zones, robust and knowledgeable methods of measurement of urban densities are called for. Such measurements can be used to support policies to avoid urban sprawl and its negative consequences while satisfying necessary requirements for quality urban living.

Urban planners use indicators such as population density measurements to support and relate a city's physical structures and its demographic dynamics. These indicators have the ability to measure growth and follow shrinking of settlements, looking to establish adequate planning strategies.

This paper showcases methods to measure population densities and capacities based on urban morphology analyses, with the assessment of densities attributed to predefined morphological units. We review already available approaches to density and capacities assessment and follow with the method based on urban morphology. Morphological typologies introduced to residential density measurements facilitate calculations due to the possibility of classification into smaller planning units. Generalisation applied from the beginning of the method enhances the overall performance of a survey. Adetailed presentation of its development and applications in several locations, both in study works and in planning praxis illustrates the method's practical application.

The actual usability of quantitative assessment must take into account the presence and role of urban voids, namely open public spaces, which can be on the border of streets and parking areas, and influence the actual quality of urban life. A number of methods to measure their quality have been briefly introduced based on the example of Lodz Study of Conditions and Directions of Planning Development (under elaboration). 


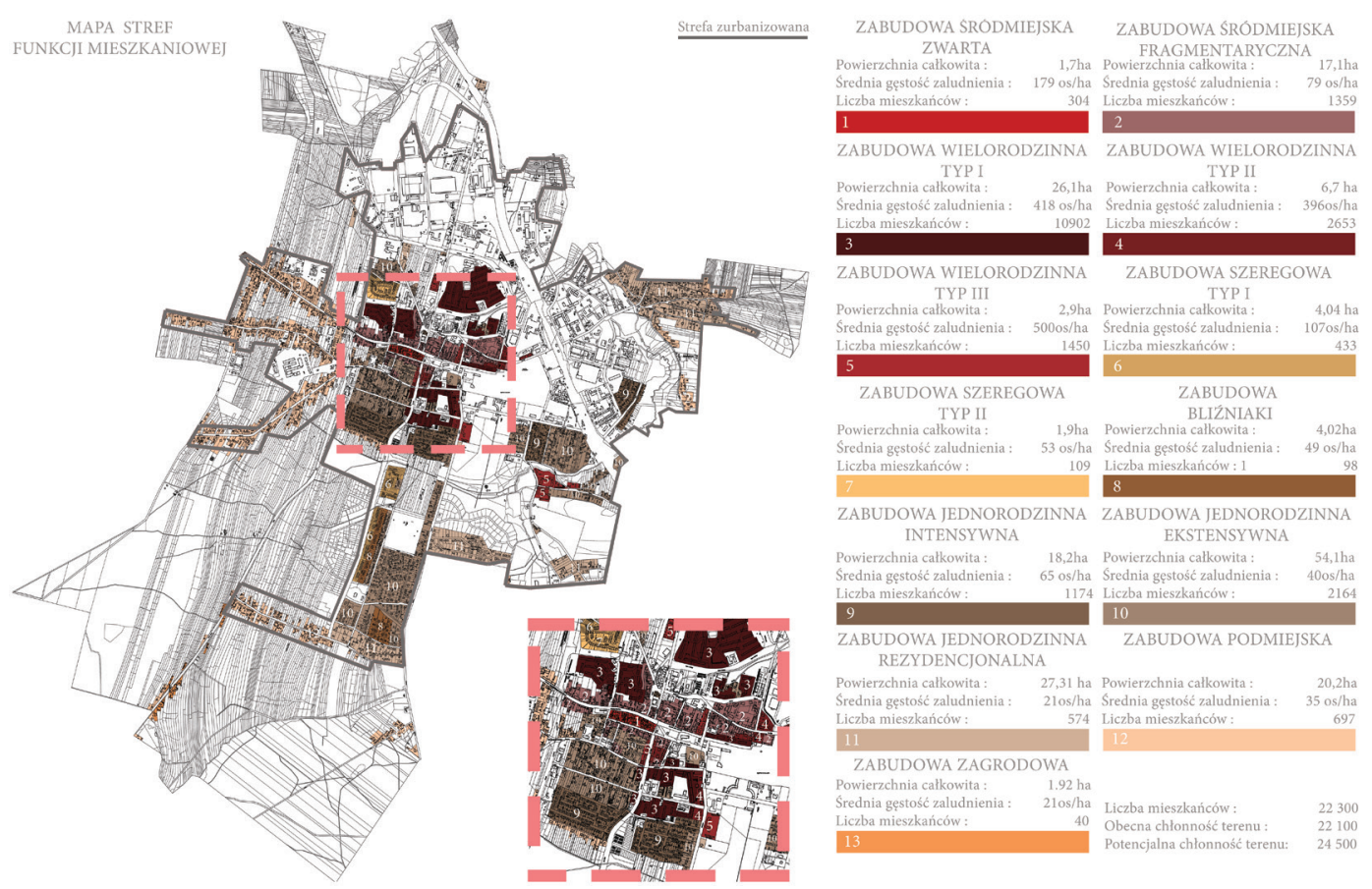

Figure 1. Urbanism and Sustainability Course, MArch 3rd sem. 2015/16, Students: Natalia Bąkowska, Sonia Dymitrowa, tutor: M. Hanzl, Institute of Architecture and Town Planning, Lodz University of Technology. Current residential development in Końskie.

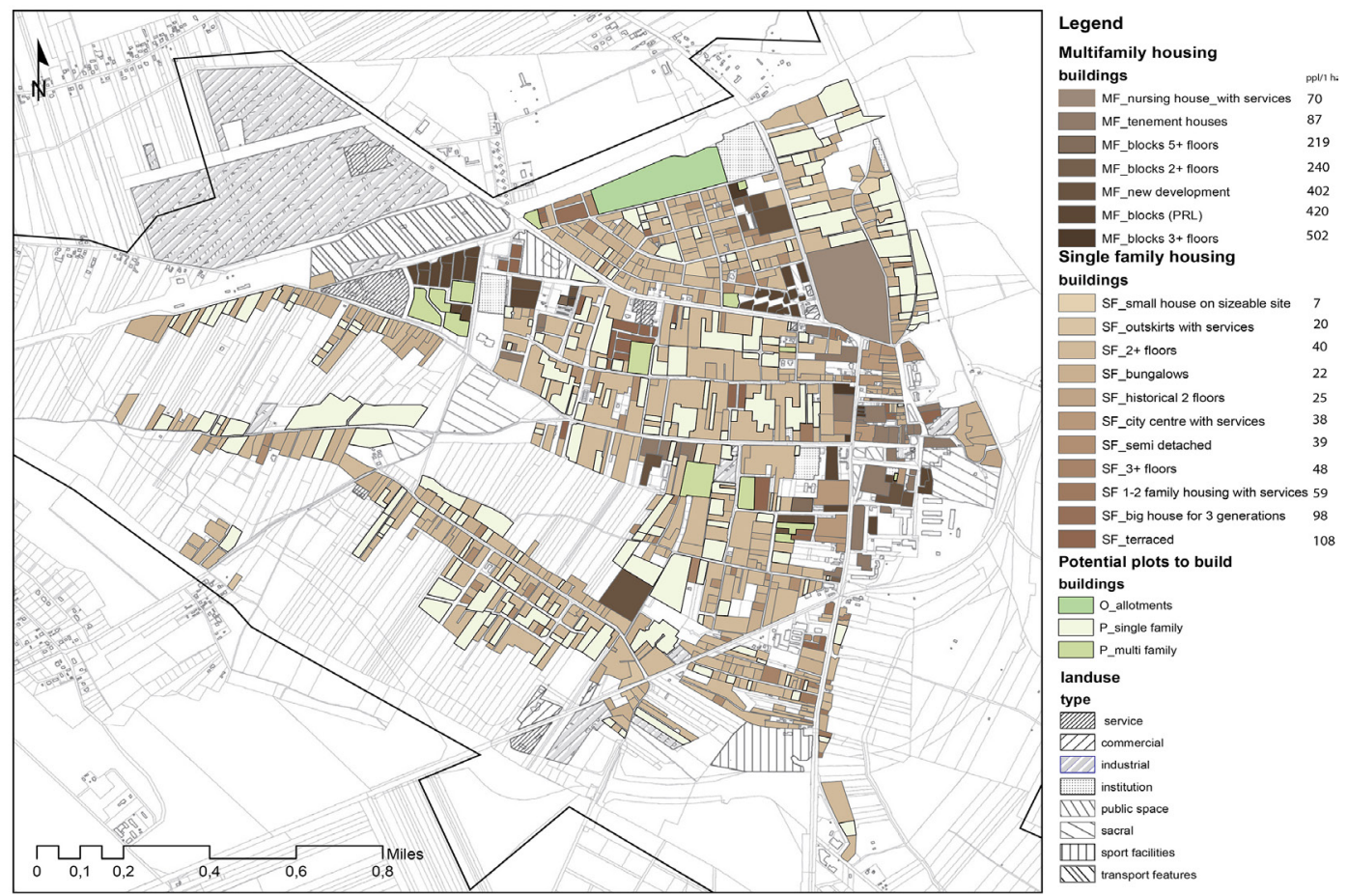

Figure 2. GIS - Parametric Description of Urban Space Course, MArch 1st sem. 2016/17,

Students: Aleksandra Grzybek, Magdalena Koczewska, Magdalena Stepniak, and Sonia Molenda, tutor: M. Hanzl, Faculty of Architecture at the Warsaw University of Technology 

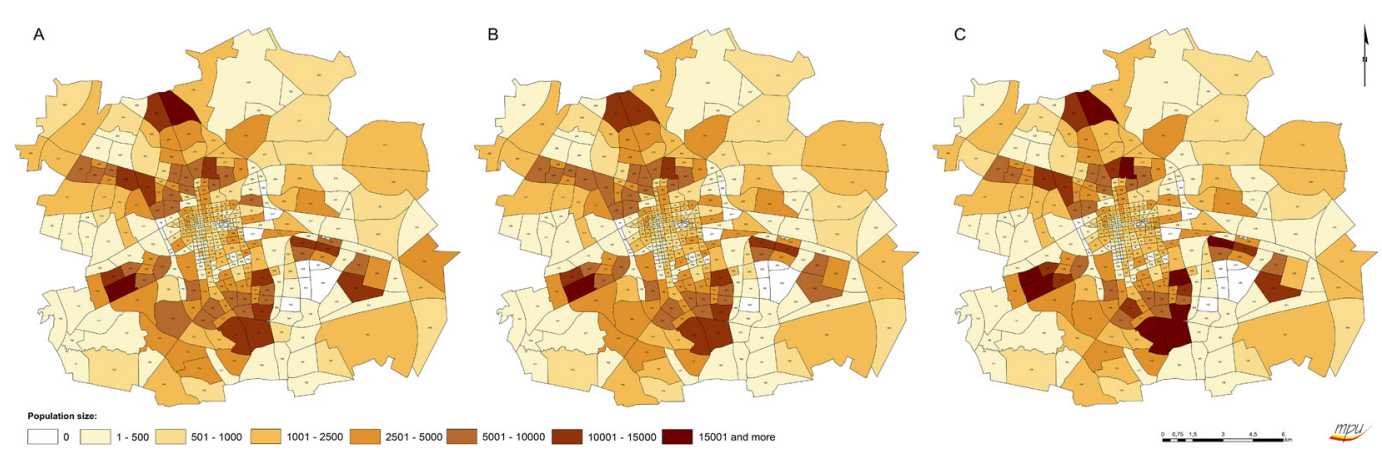

Figure 3. The population densities maps - the prognosis for years 2015 (A), 2020 (B) and 2025 (C) in transportation units. Source Study (under elaboration)

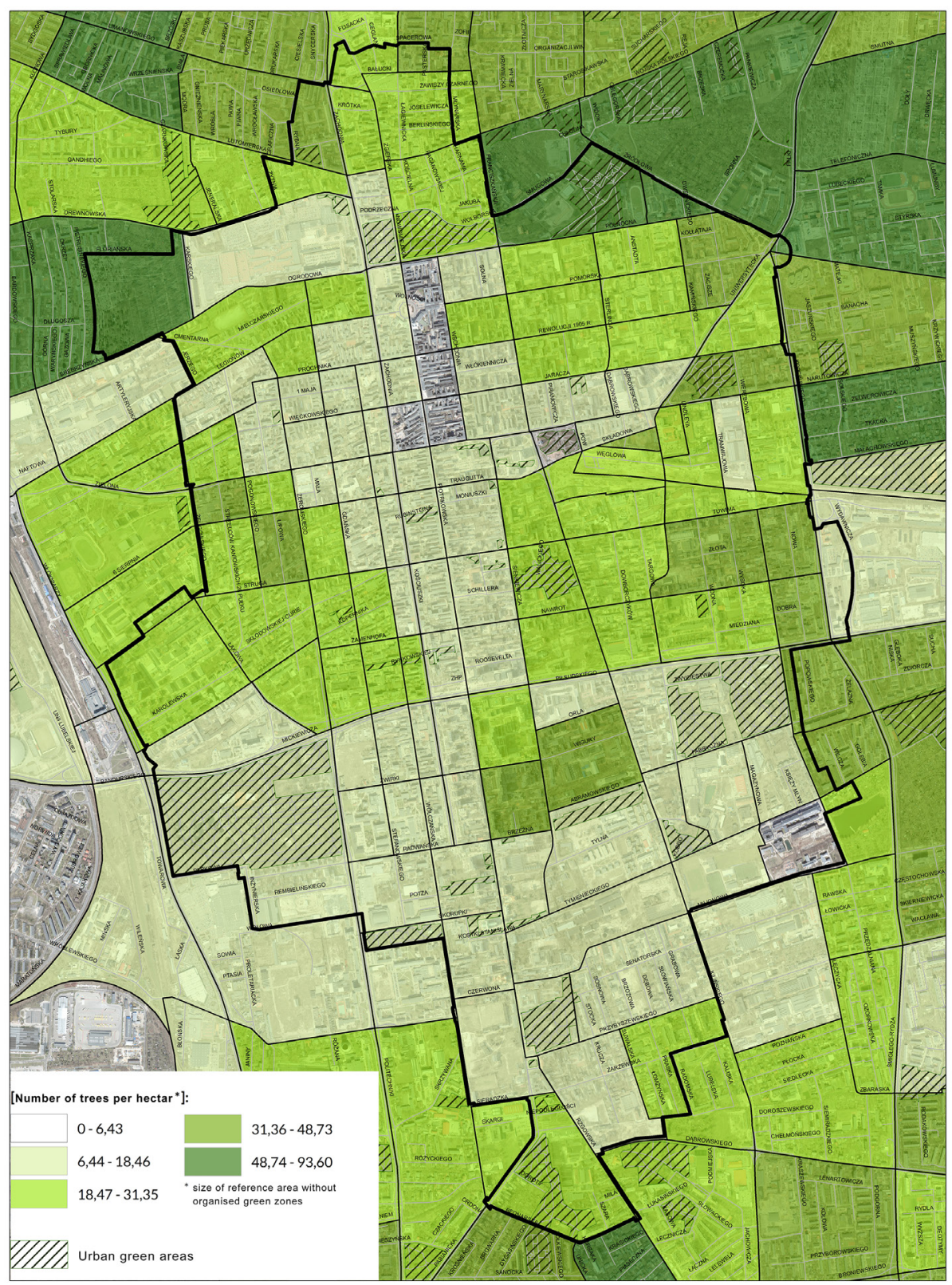

Figure 4. Tree densities in transportation areas per hectare aggregated to the municipal information system units [SIM]. Source Study (under elaboration) 


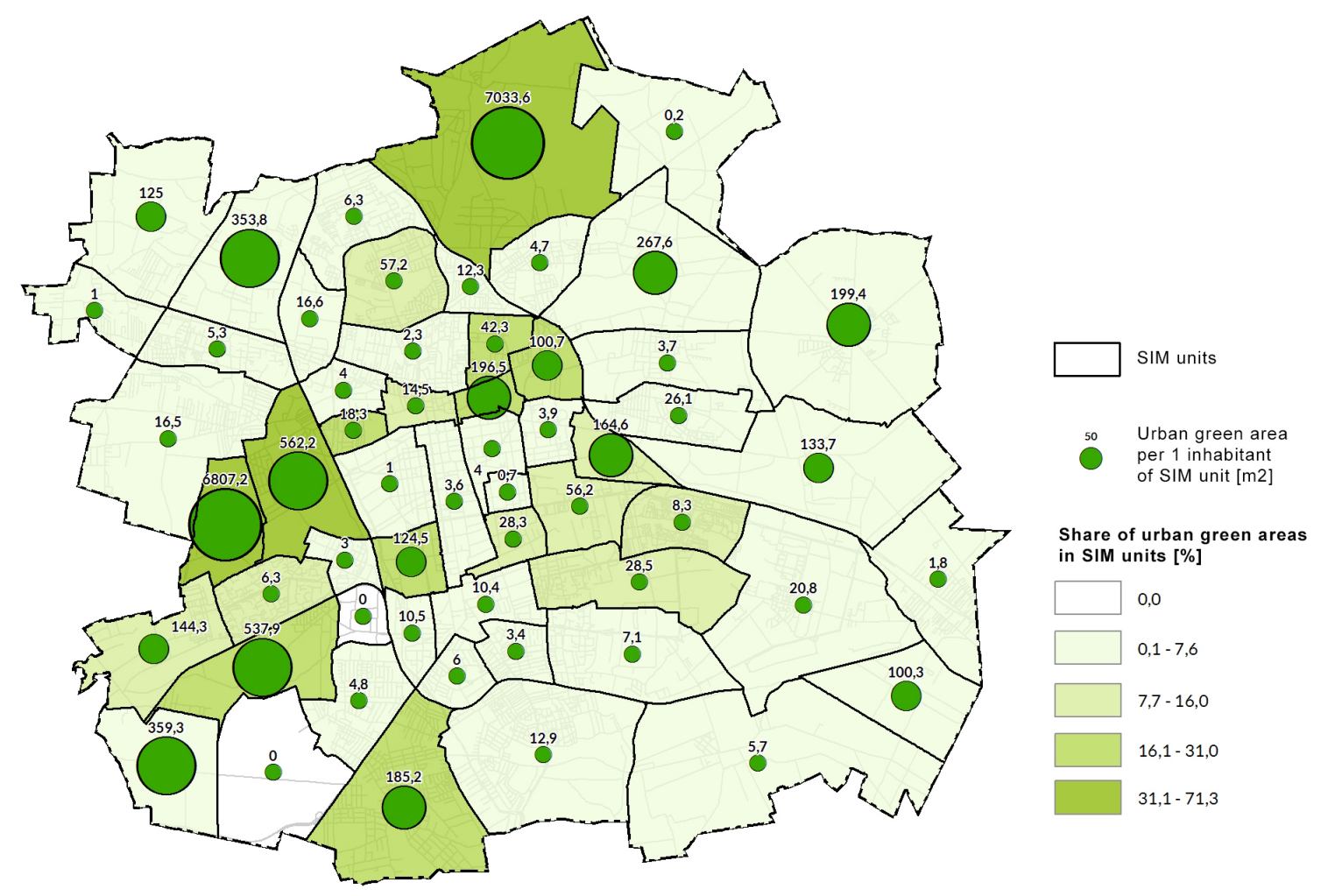

Figure 5. Public green areas (sqm per capita). Source Study (under elaboration)

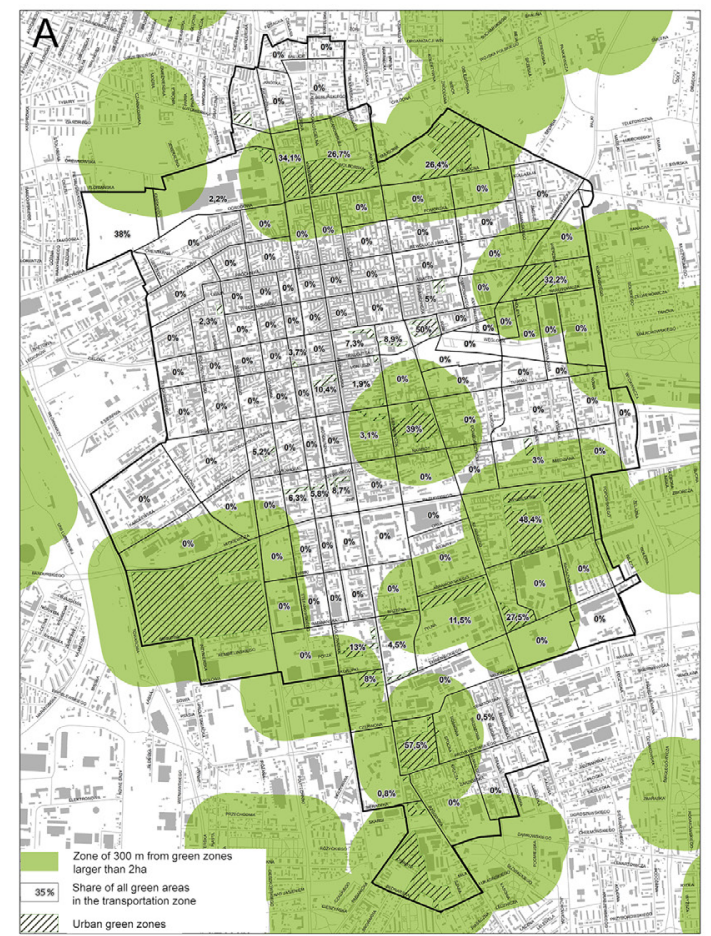

B

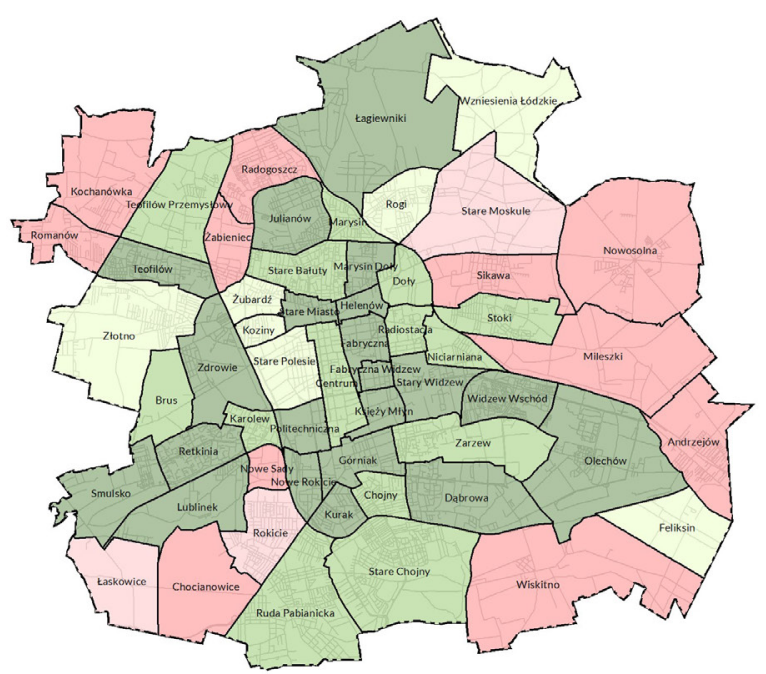

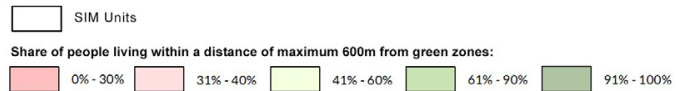

Figure 6. A. Zones within 300 meters buffer from public green areas in the Lodz downtown,

B. Share of people living within a distance of maximum $600 \mathrm{~m}$ from green zones. Source Study (under elaboration) 


\section{References}

Alexander, E. (1993) 'Density Measures: A Review and Analysis', Journal of Architectural and Planning Research 10(3), 181-202.

Angel et al. (2011) Making Room for a Planet of Cities (Lincoln Institute of Land Policy, Cambridge).

Berghauser-Pont, M. \& Haupt, P. (2010) Space Matrix: Space, Density and Urban Form (NAI Publishers, Netherlands).

Baker, N.J. and Slater, T.R. (2000) 'Morphological regions in English medieval towns', in Whitehand, J.W.R. and Larkham, P.J. (eds) Urban landscapes: international perspectives Routledge, London

Churchman, A. (1999) 'Disentangling the Concept of Density', Journal of Planning Literature, 13(4), 389-411.

Clark, C. (1951) 'Urban Population Densities', Journal of the Royal Statistical Society, 114, 490-496.

Faludi, A. and Waterhout, B (2006) 'Introducing Evidence-Based Planning', disP Plan. Rev. 165, 4-13.

Hanzl, M. (2003) 'Virtual City Models as a Tool for Urban Tissue Evaluation' in: 23rd Urban Data Management Symposium Proceedings (Prague).

Hanzl, M. and Bezerra, L. (in press) 'Quantifying Sustainable Growth through a Morphological Approach Comparison to Population Density Measurements' in: Computational Science and Its Applications - ICCSA 2017. 17th International Conference, Trieste Italy, July 4-7, 2017 , Proceedings (Springer).

INSPIRE (2016) Infrastructure for Spatial Information in Europe Homepage, http:// inspire.ec.europa.eu/ accessed in 15 April 2016.

International Organization for Standardization (2016) ISO 37120:2014 Sustainable Development of Communities - Indicators for City Services and Quality of Life, https:// www.iso.org/standard/62436.html accessed in 02 June 2016

Lodz City Council (2002) 'Study of Conditions and Directions of Spatial Development of Lodz', Resolution No. LXXVII/1793/02 of
City Council in Lodz of 03.04.2002 chief designer Wiśniewski, M.

Lodz City Council (under elaboration) 'Study of Conditions and Directions of Spatial Development of Lodz'. Resolution No. LXVI/1415/13 of City Council in Lodz of 03.07.2013 about the document's initiation.

Newman, P., Kenworthy, J. (1999) Sustainability and Cities: Overcoming Automobile Dependence (University of Chicago Press, Chicago).

Oh, K., Jeong Y., Lee D., Lee W. (2004) Determining Sustainable Development Density using the Urban Carrying Capacity Assessment System (CASA Working Papers Series 78).

Polish Parliament (2015) 'Amending Act for the Strengthening of Landscape Protection', in Polish 'Ustawa o zmianie niektórych ustaw w związku ze wzmocnieniem narzędzi ochrony krajobrazu'. Dz.U. 2015.744 (24.04.2015)

Roloff, A. (2016) Urban Tree Management for the Sustainable Development of Green Cities (Wiey-Blackwell, Dresden).

Smith, A.D., Crooks, A.T. (2010) From Buildings to Cities: Techniques for the Multi-Scale Analysis of Urban Form and Function (CASA Working Papers Series 155).

Warsza, R. (2012) 'Urbanizacja strefy podmiejskiej na przykładzie wybranych gmin łódzkiego obszaru metropolitalnego po roku 1990', unpublished $\mathrm{PhD}$ thesis (Lodz University of Technology, Lodz). 